Sains Malaysiana 49(4)(2020): 809-816

http://dx.doi.org/10.17576/jsm-2020-4904-10

\title{
3D Titanium Scaffold Properties and Osteogenesis of Stem Cells
}

(Sifat Perancah Titanium 3D dan Osteogenesis Sel Stem)

\author{
Rohaya Megat Abdul WahaB*, Manal Nabil Hagar, Nur Atmaliya Luchman, Farinawati Yazid \& \\ SHAHRUL HISHAM ZAINAL ARIFFIN
}

\begin{abstract}
Studies on porous titanium for use in dental applications have been growing due to their excellent properties such as low elastic modulus, biocompatibility and excellent strength. The porosity and pore size of titanium scaffold play an important role in bone formation. Thus, this paper reviews the properties of titanium scaffold and the relationship between the porosity and pore size of titanium with the osteogenesis of stem cells in respect of its mechanical properties and biological assessment. From this review, it was found that a pore size of less than $300 \mu \mathrm{m}$ allows for good vascularization that can lead to direct osteogenesis without an interphase of cartilage formation. The minimum requirement for pore size is approximately $100 \mu \mathrm{m}$ to assist in the migration requirement, cell size and transport, as a smaller pore size causes a hypoxic condition and induces osteochondral formation before osteogenesis, while a pore size from 500 to $1000 \mu \mathrm{m}$ affects the differentiation of the stem cells. In addition, it was found that high porosity induces osteogenesis. The average porosity of the scaffold for cell proliferation was between 25-50 $\mathrm{mm}$. In conclusion, highly porous titanium is a useful modern material for creating $3 D$ structures for bone regeneration and implant fixation.
\end{abstract}

Keywords: Bone regeneration; pore size; porosity; stem cell; titanium scaffold

\section{ABSTRAK}

Kajian mengenai titanium berliang telah berkembang pesat dalam aplikasi pergigian disebabkan oleh ciri-ciri istimewanya seperti modulus kenyal, bioserasi dan kekuatan bahan. Keliangan dan saiz liang perancah titanium memainkan peranan yang penting dalam proses pembentukan tulang. Ciri-ciri perancah titanium dan hubungan antara keliangan dan saiz liang titanium dengan osteogenesis sel stem serta perkaitannya dengan sifat mekanik dan penilaian biologi diulas dalam artikel ini. Daripada ulasan ini, didapati bahawa saiz liang yang kurang daripada 300 $\mu m$ membenarkan vaskularisasi yang baik yang boleh menyebabkan osteogenesis secara langsung tanpa interfasa daripada pembentukan rawan. Saiz liang minimum yang diperlukan adalah lebih kurang 100 um dan ia sesuai bagi saiz sel dan pengangkutan serta membantu dalam migrasi sel kerana saiz liang yang lebih kecil boleh menyebabkan keadaan hipoksia dan merangsang pembentukan osteokondral sebelum osteogenesis. Saiz liang antara 500 hingga $1000 \mu$ m pula memberi kesan kepada pembezaan sel stem. Selain daripada itu, didapati bahawa peningkatan keliangan juga dapat merangsang osteogenesis. Purata keliangan bagi perancah untuk membantu proliferasi sel adalah antara 25-50 $\mu \mathrm{m}$. Kesimpulannya, titanium yang mempunyai keliangan yang tinggi sesuai menjadi bahan moden untuk pembentukan struktur $3 D$ bagi penjanaan semula tulang dan penetapan implan.

Kata kunci: Keliangan; penjanaan semula tulang; perancah titanium; saiz liang; sel stem

\section{INTRODUCTION}

Titanium and titanium alloys, based on their physical and chemical properties, appear to be especially suitable for dental implants, prostheses and many load-bearing orthopaedic applications. For the construction of endosseous implant devices, titanium and its alloys have become well-accepted and can be considered the materials of choice (Dabrowski et al. 2010). Titanium scaffold is considered to offer a new opportunity in dental science to enhance tissue formation due to its porosity that accommodates cell proliferation and differentiation
(Rakhmatia et al. 2013). As compared to other types of scaffold (Table 1), the titanium scaffold fulfils the purposes of scaffolds such as biocompatibility, the ability to be sterilized, mechanical stability, and porosity, and also promotes osteogenic differentiation (Tamaddon et al. 2017). Titanium is highly recommended for use in dental applications because of its excellent mechanical properties that help to stabilize the bone graft under the membrane. Its elasticity prevents mucosal compression; its stability inhibits graft displacement; its rigidity prevents contour collapse, and its porosity accommodates cell proliferation and differentiation, which will eventually enhance tissue 
formation. Furthermore, its plasticity permits bending and adaptation to any bony defect (Rakhmatia et al. 2013).

Stem cells are required in most research that involves cell differentiation because they have the unique ability to self-renew and differentiate into many cell types (Yazid et al. 2011). Porous surfaces are important in bone formation because they permit the mesenchymal stem cells to proliferate, provide greater mechanical stability and improve the mechanical interlocking between the titanium and surrounding bone. Large pores allow good vascularization that leads to direct osteogenesis, while small pores induce osteochondral formation before osteogenesis. The porosity and pore size of titanium scaffold play a significant role in bone regeneration (Karageorgiou \& Kaplan 2005).

TABLE 1. Comparison of the properties of different scaffolds

\begin{tabular}{|c|c|c|c|c|c|c|}
\hline & & Types of scaffold & Examples & Advantages & Disadvantages & Properties \\
\hline \multirow[t]{5}{*}{1} & & $\begin{array}{l}\text { nic material (Li \& } \\
\text { ey 2011) }\end{array}$ & & & & \\
\hline & a. & Ceramic & $\begin{array}{l}\text { Hydroxyapatite } \\
\text { (HA), tricalcium } \\
\text { phosphate (TCP) }\end{array}$ & $\begin{array}{l}\text { Widely used because } \\
\text { the chemical nature is } \\
\text { identical to the bone }\end{array}$ & $\begin{array}{l}\text { Brittle and slow } \\
\text { biodegradation } \\
\text { (O'brien 2011) }\end{array}$ & $\begin{array}{l}\text { Excellent } \\
\text { biocompatibility, } \\
\text { high mechanical } \\
\text { properties, very low } \\
\text { elasticity, promotes } \\
\text { cell adhesion and } \\
\text { enhances osteogenic } \\
\text { differentiation } \\
\text { (O'brien 2011) }\end{array}$ \\
\hline & b. & Non-ceramic & $\begin{array}{l}\text { Calcium phosphate } \\
\text { - based cement } \\
\text { (CPCs) }\end{array}$ & $\begin{array}{l}\text { CPCs are injectable } \\
\text { so can be handled by } \\
\text { surgeon and set in the } \\
\text { bone site (O'brien } \\
\text { 2011) }\end{array}$ & $\begin{array}{l}\text { Exothermic reaction, } \\
\text { lack of macroporosity, } \\
\text { and their intrinsic } \\
\text { radioopaque nature } \\
\text { cause difficulty in } \\
\text { detecting the healing } \\
\text { of bone (Li \& Wozney } \\
\text { 2011) }\end{array}$ & $\begin{array}{l}\text { High solubility in vivo } \\
\text { which increased the } \\
\text { bone formation }\end{array}$ \\
\hline & c. & $\begin{array}{l}\text { Calcium sulphate } \\
\left(\mathrm{CaSO}_{4}\right)\end{array}$ & $\mathrm{CaSO}_{4}$ & $\begin{array}{l}\text { Cost reduction, and } \\
\text { rapid resorption (Asadi- } \\
\text { Eydivand et al. 2018) }\end{array}$ & $\begin{array}{l}\text { Poor mechanical } \\
\text { properties (Asadi- } \\
\text { Eydivand et al. 2018) }\end{array}$ & $\begin{array}{l}\text { Good stability, } \\
\text { degradation, and poor } \\
\text { mechanical properties }\end{array}$ \\
\hline & d. & Metals & Titanium scaffold & $\begin{array}{l}\text { Non-toxicity, excellent } \\
\text { biocompatibility, high } \\
\text { porosity and surface } \\
\text { area }\end{array}$ & $\begin{array}{l}\text { Not biodegradable } \\
\text { (Chocholata et al. } \\
\text { 2019) }\end{array}$ & $\begin{array}{l}\text { Good } \\
\text { biocompatibility, } \\
\text { sterilized, promotes } \\
\text { osteogenic } \\
\text { differentiation, } \\
\text { mechanical stability, } \\
\text { strength, along with } \\
\text { permeability and } \\
\text { corrosion resistance } \\
\text { (Dabrowski et al. } \\
\text { 2010) }\end{array}$ \\
\hline
\end{tabular}




\begin{tabular}{|c|c|c|c|c|c|c|}
\hline & e. & $\begin{array}{l}\text { Bioglasses } \\
\text { (silicate } \\
\text { and borate } \\
\text { compositions) }\end{array}$ & $\begin{array}{l}\text { Biogran (BIOMET } \\
\text { 3i, Palm Beach } \\
\text { Gardens, FL), } \\
\text { Novabone (Nova- } \\
\text { Bone Products } \\
\text { LLC) }\end{array}$ & $\begin{array}{l}\text { High solubility which } \\
\text { increases the bone } \\
\text { regeneration (Hoppe \& } \\
\text { Boca 2014) }\end{array}$ & Lack of porosity & $\begin{array}{l}\text { Good mechanical } \\
\text { properties, high } \\
\text { solubility, and non- } \\
\text { cytotoxic degradation } \\
\text { (Fernando et al. 2016) }\end{array}$ \\
\hline 2 & & Natural polymers & $\begin{array}{l}\text { Fibrin, hyaluronic } \\
\text { acid, proteoglycan, } \\
\text { alginate, chitosan } \\
\text { and collagen } \\
\text { (decalcified bone } \\
\text { matrix (DBM), } \\
\text { fibrillar collagen, } \\
\text { and gelatin) }\end{array}$ & $\begin{array}{l}\text { Excellent } \\
\text { biocompatibility, } \\
\text { rapid resorption, and } \\
\text { identified in the early } \\
\text { stages of wound healing } \\
\text { (Alaribe et al. 2019) }\end{array}$ & $\begin{array}{l}\text { Disease transmission } \\
\text { and sterilization }\end{array}$ & $\begin{array}{l}\text { Excellent } \\
\text { biocompatibility, } \\
\text { high porosity } \\
\text { which increases } \\
\text { cell infiltration and } \\
\text { vascularization, } \\
\text { poor mechanical } \\
\text { properties (O'brien } \\
\text { 2011), biodegradable } \\
\text { with low toxicity, } \\
\text { supports cell } \\
\text { adhesion and growth } \\
\text { (Thavornyutikarn et } \\
\text { al. 2014) }\end{array}$ \\
\hline 3 & & $\begin{array}{l}\text { Synthetic } \\
\text { polymers }\end{array}$ & $\begin{array}{l}\text { Polystyrene, } \\
\text { polypropylene } \\
\text { fumarate, } \\
\text { polyethylene } \\
\text { glycol, poly-l- } \\
\text { lactic acid (PLLA), } \\
\text { polyanhydride, } \\
\text { polyphosphazenes } \\
\text { (Li \& Wozney } \\
\text { 2011), polyglycolic } \\
\text { acid (PGA) and } \\
\text { poly-dl-lactic- } \\
\text { co-glycolic acid } \\
\text { (PLGA) and } \\
\text { poloxamers } \\
\text { (O’brien 2011) }\end{array}$ & $\begin{array}{l}\text { Sterilization is } \\
\text { easy, reproducible } \\
\text { manufacture, and } \\
\text { tailored control }\end{array}$ & $\begin{array}{l}\text { Chronic inflammatory } \\
\text { response, complex } \\
\text { architecture, toxic } \\
\text { degradation (O’brien } \\
\text { 2011) and poor } \\
\text { clearance particularly } \\
\text { for the high molecular } \\
\text { weight polymer (Li \& } \\
\text { Wozney 2011) }\end{array}$ & $\begin{array}{l}\text { Poor biocompatibility, } \\
\text { potential toxic } \\
\text { degradation and good } \\
\text { stability (Alaribe et } \\
\text { al. 2019) }\end{array}$ \\
\hline 4 & & $\begin{array}{l}\text { Composite } \\
\text { (combination } \\
\text { of ceramic with } \\
\text { polymers or } \\
\text { combination of } \\
\text { natural polymers } \\
\text { with synthetic } \\
\text { polymers) }\end{array}$ & $\begin{array}{l}\text { Hyaluronic acid- } \\
\text { impregnated PLA } \\
\text { sponge }\end{array}$ & $\begin{array}{l}\text { Takes the benefits from } \\
\text { different materials that } \\
\text { are exploited }\end{array}$ & $\begin{array}{l}\text { Poor mechanical } \\
\text { properties and } \\
\text { immune-response } \\
\text { difficulties } \\
\text { (Chocholata et al. } \\
\text { 2019) }\end{array}$ & $\begin{array}{l}\text { Depend on the } \\
\text { materials that are } \\
\text { exploited }\end{array}$ \\
\hline
\end{tabular}

\section{PROPERTIES OF TITANIUM SCAFFOLD AND ITS ROLE IN REGENERATION}

Animal studies have reported that titanium (Ti) is a safe metal for an implant and the bone directly fused to it (Dabrowski et al. 2010). Porous titanium scaffold has many properties such as biocompatibility, the ability to be sterilized, promoting osteogenic differentiation, mechanical stability, strength, Young's modulus, along with permeability and corrosion resistance (Dabrowski et al. 2010). Both bulk material of titanium and sponge- 
like titanium have been used for tissue engineering purposes. Sponge-like titanium consists of titanium fibres that are sintered together to create a mesh structure. The mesh structures are advantageous due to their flexibility, strength, biocompatibility, porosity, and interconnectivity. Titanium's strength is useful for bone replacement as its flexibility distributes the stresses between the implant and tissue. In addition, the porosity of Ti allows tissue ingrowth and stabilization, in addition to which the design of titanium can be varied by varying the density and diameter of the fibres.

The biocompatibility of titanium mesh is determined by the response of the tissue and the absence of allergic reaction to titanium. A study that compared the tissue responses of three mesh materials showed that the titanium mesh induced a better tissue response than Fecralloy and stainless steel 316L (van den Dolder \& Jansen 2007). In addition, this study found that titanium does not cause allergies. Pattanayak et al. (2011) showed how new bone penetrated into the pores and directly bonded to the walls after implantation of bioactive Ti into the femur of white rabbit. This scaffold was fabricated by selective laser melting and was treated chemically by $\mathrm{NaOH}$ and HCL to provide bioactivity. In an orthopaedic implant application, porous titanium showed a relatively high permeability but had low resistance to corrosion when compared to a cast titanium (Dabrowski et al. 2010). Pores play an important role in bone tissue formation because they allow the migration and proliferation of osteoblast and mesenchymal cells. Porosity facilitates the circulation of body fluids and encourages the growth of cells (Arifin et al. 2017). According to Karageorgiou and Kaplan (2005), direct osteogenesis was noticed in the porous scaffold, while there was no new bone formation in the non-porous scaffold, which indicated the necessity for porosity.

A study that investigated the influence of hierarchical hybrid micro/nano-textured titanium surface features on osteoblast differentiation found that this surface can promote bone formation and accelerates bone growth (Meng et al. 2013). Another type of Ti scaffold is titanium web (TW), which is flammable, unstable and difficult to prepare, and it was demonstrated that TW with a diameter of $8 \mathrm{~mm}$ is essential for ectopic bone formation. Also, it was determined that a higher porosity and higher pore size of TW showed greater bone formation (Amemiya et al. 2012). The scaffold for bone defect regeneration should show a high mechanical property and have open porosity to ensure bone ingrowth such as in metal. It was determined that open porosity is an important factor in osteogenesis (Otsuki et al. 2006). Salt leaching, gas foaming, phase separation, freeze-drying, and sintering are the most common techniques that are used to create porosity in biomaterials (Karageorgiou \& Kaplan 2005). The pores of the structure must be interconnected in order to ensure bone growth. A porous structure can be manufactured by freeze-casting, the space holder technique, rapid prototyping and laser processing. Rapid prototyping and laser processing are able to generate porous titanium with a simple pore architecture, while freeze-casting and the space holder technique form a porous material with randomly distributed pores (Barbas et al. 2012). According to Fujibayashi et al. (2004), the macroporous structure of porous titanium block with approximately $40 \%$ porosity was more complex and effective for osteogenesis than titanium fibre mesh cylinders with approximately $40-60 \%$ porosity. This was concluded by implanting them into the dorsal muscle of a mature beagle dog after undergoing specific chemical and thermal treatments.

The minimum requirement for pore size is $100 \mu \mathrm{m}$ due to the cell size, but a pore size greater than $300 \mu \mathrm{m}$ was recommended, as it enhances new bone formation (Karageorgiou \& Kaplan 2005). A pore size below 100 $\mu \mathrm{m}$ in an in vivo study showed fibrous tissue formation, while a bigger pore size $(150 \mu \mathrm{m})$ favoured bone tissue formation (Wysocki et al. 2016). The highest cell proliferation was shown in Ti-6AL-4V alloy scaffold with $200 \mu \mathrm{m}$ pore size (Wysocki et al. 2016). In addition, Stangl et al. (2001) showed that a $200 \mu \mathrm{m}$ pore size is the most preferred (Wysocki et al. 2016). On the other hand, pore sizes from 500 to $1000 \mu \mathrm{m}$ can affect the differentiation of cells (Van Bael et al. 2012). A study proved that Ti-6AL-4V alloy scaffold with pore sizes of $500,600,700$, and $900 \mu \mathrm{m}$ was filled by cells after 6 weeks in $100 \%, 44 \%, 10 \%$, and $0 \%$ of the scaffold, respectively (Wysocki et al. 2016). Chen et al. (2009) demonstrated that when reducing the particle size of the titanium, the surface energy increased on the alkaliheated treated porous and non-porous titanium, which will lead to a higher apatite-inducing ability. A study showed that more bone formation was seen in rats that received two titanium scaffolds than rats with empty defects. These scaffolds have different structures (Ti-120, Ti-230) due to their different strut size. Reducing the strut scaffold size by $50 \%$ in the Ti-120 structure resulted in a large decrease of the elastic modulus and showed more bone ingrowth (Wysocki et al. 2016).

Continuous growth was noted in a random pore size scaffold, while discontinuous growth was observed in the scaffold with pores of the same size and a solid wall. Faster healing was detected in the whole space of the defect (Simon et al. 2003). Many studies have proved that high porosity induces osteogenesis. According to Luthringer et al. (2013), the optimum porosity of scaffold for cell proliferation was $25-50 \mu \mathrm{m}$. Porous titanium scaffold provided mechanical support in an early phase and it facilitated bone formation, resulting in a high mechanical strength of the large bone defects treated (Van der Stok et al. 2013). 


\section{COATING OF 3D TITANIUM SCAFFOLD}

Fabricated porous Ti/HA may be an appropriate material for future bio-medical applications (Raza et al. 2015). Although hydroxyapatite coating is beneficial for bone formation, a study hypothesized that the titanium scaffold has an intrinsic potential to induce bone formation without the need for a hydroxyapatite coating. This was concluded by comparing titanium scaffold coated with hydroxyapatite and non-coated titanium in vitro (Tamaddon et al. 2017). Coating the titanium alloy surface with sintered titanium beads in the tibiae of sheep increased the strength of the implant. However, coating with hydroxyapatite did not result in a significant osseointegration (Karageorgiou \& Kaplan 2005).

Acid-etched coating (higher surface roughness) for a Ti implant demonstrated a higher osseointegration when compared with grit-blasted and fibre mesh coating (lower surface roughness) in the femurs of rabbit (Karageorgiou \& Kaplan 2005). Coating the titanium alloy implant of a dog mandible with $50 \mu \mathrm{m}$ of porous hydroxyapatite did not increase the osseointegration. However, there was more bone formation in the maxilla. Therefore, it was indicated that coating with hydroxyapatite had a useful affect for areas with poor bone (Karageorgiou \& Kaplan 2005). The sintering behaviour of titanium-blended 316L SS powder compacts showed a higher rate of shrinkage in titanium-blended 316L SS as compared to non-blended compacts because of the faster annihilation of porosity, which promotes osteogenesis (Aslam et al. 2014). Jemat et al. (2018) demonstrated that titanium alloys coated with yttria-stabilized zirconia (YZP/TiO2) had a higher porosity and surface roughness when compared with the pure YZP coating, which is beneficial for cell growth and attachment.

Polyether ether ketone (PEEK) is a favorable material for interbody spinal fusion. Titanium-coated PEEK had significantly greater shear strength than uncoated PEEK. The shear strength was greater in deeply porous titanium due to greater osseointegration, which is not available in the uncoated PEEK. This combination reduced the problem that results from the fibrous tissue that forms along the PEEK and it is beneficial for spinal fusion cages (Guyer et al. 2016). Smooth titanium stimulated a greater response than PEEK. However, the rough titanium alloy stimulated cells to create an osteogenicangiogenic microenvironment. Thereby, the response was greater than with the smooth titanium (Guyer et al. 2016). Seeding bone marrow stromal cells onto titanium web (TW) indicated the efficacy of TW as a bone scaffold material (Vehof et al. 2001). A few studies of titanium web in animal experiments reported that apatite coating of TW provided better bone formation (Hayakawa et al. 2008).

Hibi et al. (2006) used tissue-engineered osteogenic material (TEOM) comprising autologous mesenchymal stem cells (MSCs), platelet-rich plasma (PRP) and calcium chloride solution with thrombin for the alveolar cleft osteoplasty of a 9-year old female patient. The alveolar cleft was supported with a titanium mesh plate to provide space without disturbing the blood supply. After nine months, post-operatively the case showed $79.1 \%$ of regenerated bone. A similar study with titanium indicated that $\mathrm{TiO} 2$ coating aids in bone remodelling and the growth of osteoblasts. $\mathrm{TiO} 2$ has a compressive strength and it secreted higher bone markers when compared with silica and calcium phosphate (Mediaswanti et al. 2013). The application of a thicker porous oxide film on the surface of titanium screws in a tibia defect showed more bone formation when compared to thinner non-porous oxide layers (Sul et al. 2002).

\section{EFFECT OF POROSITY AND COATING IN OSTEOGENESIS}

The role of porosity and interconnectivity in scaffolds is to facilitate cell migration within the porous structure so that cell growth is enabled while overcrowding is avoided. In addition, the porosity enhanced the cell proliferation rate, which might be due to the transport of nutrients and oxygen in vitro (Loh \& Choong 2013). Many studies have proved that high porosity induces osteogenesis. Dental implants coated with structured titanium with $44 \%$ and $48 \%$ porosity. These implants were grafted in a canine mandible and femoral defect and the results showed more bone formation for the higher porosity at the initial timepoints in the mandible ( 2 and 4 weeks) and at all time points in the femur (14 weeks) (Karageorgiou $\&$ Kaplan 2005). More bone formation was observed in rat calvarial defects when the pore size was increased from 35.4 to $47.7 \%$. However, when nickel-titanium implants with $66 \%$ and $47 \%$ porosity were implanted in rat femoral defects, no statistical differences could be detected in bone formation, as the porosity was between 40-60\% (Kujala et al. 2003).

Many studies have suggested that the minimum requirement for pore size is above $100 \mu \mathrm{m}$. A study in the distal femoral cortex of rabbit showed that bone formation was delayed in laser-textured titanium alloy (Ti6Al4V) with $100 \mu \mathrm{m}$ pore size when compared with $200 \mu \mathrm{m}$ and $300 \mu \mathrm{m}$ (Götz et al. 2004). This study demonstrated that $200 \mu \mathrm{m}$ was the optimal pore size for laser-textured titanium alloy (Ti6Al4V) because the osseointegration was faster than for the other pore sizes (Götz et al. 2004). A study by Liu et al. (1999) noted that, as long as the pore size is between 100 and $300 \mu \mathrm{m}$ and the porosity between $40-60 \%$, no differences in bone formation can be shown. For example, nitinol implants with the same thickness and different pore sizes $(353$, 218 , and $179 \mu \mathrm{m}$ ) with respective porosities of $43 \%$, $54 \%$ and $51 \%$ were placed in cranial defects in rabbits and showed no differences in bone formation. Another study indicated no statistical differences in bone ingrowth, but more fibrosis was detected in nitinol implants with 
$505 \mu \mathrm{m}$ pore size compared to $209 \mu \mathrm{m}$ pore size that were implanted in rat femoral defects (Kujala et al. 2003).

The advantage of larger compared to smaller diameter porosity is that chondrogenesis occurred before osteogenesis in small diameter tunnels, while in large diameter tunnels the bone was formed directly. The reason for direct osteogenesis in the large diameter was due to the higher oxygen tension and supply of nutrients (Karageorgiou \& Kaplan 2005).

THE EFFECT OF PORE SIZE AND POROSITY ON MECHANICAL PROPERTIES AND BIOLOGICAL RESPONSE OF POROUS TITANIUM SCAFFOLDS

For a successful grafting, a balance between the mechanical properties (stiffness and strength) and microarchitecture (porosity and pore size) should be achieved. Porous titanium scaffold was prepared in two types of porosities, therefore, their mechanical properties mimic the cortical and trabecular bone. Unlike the open porosity ranges that fitted well with the cortical bone, the trabecular ones were lower (Torres-Sanchez et al. 2017).

In the biological aspect, scaffolds with the lowest pore ranges $(45-106 \mu \mathrm{m})$ showed the highest number of cell attachments in the early stage. Furthermore, the proliferation of cells is slower than the larger pore size. The optimal pore microarchitecture (i.e. pore size and porosity) for scaffolds to be used in bone grafting for cortical bone was set to $<212 \mu \mathrm{m}$ with volumetric porosity values of $27-37 \%$, and for trabecular tissues to $300-500 \mu \mathrm{m}$ with volumetric porosity values of $54-58 \%$ (Torres-Sanchez et al. 2017).

\section{CONCLUSION}

Titanium has become a new class of material that is used for various dental engineering applications. Titanium and titanium alloy can be considered the materials of choice for dental implants, prostheses and many load-bearing orthopaedic applications. This review provides an overview that facilitates the understanding of the effect of porosity and pore size on the cellular behaviour and mechanical properties of a titanium scaffold. Interconnected porous scaffold networks that enable the transport of nutrients, removal of wastes, as well as facilitating the proliferation and migration of cells, are essential. The porosity and pore size influence the cell behaviour as well as determining the final mechanical property of the scaffold. Porosity is an important factor in osteogenesis, where it plays a significant role. Chondrogenesis occurred before osteogenesis in small diameter tunnels, while in large diameter tunnels the bone was formed directly. The appropriate pore size that enhances new bone formation is between 100 and $300 \mu \mathrm{m}$, while the average porosity of scaffold for cell proliferation is $25-50 \%$.

\section{ACKNOWLEDGEMENTS}

This review was funded by the Fundamental Research Grant Scheme (FRGS), Ministry of Higher Education, Malaysia (FRGS/1/2015/SG05/UKM/02/2).

\section{REFERENCES}

Alaribe, F.N., Manoto, S.L. \& Motaung, S.C. 2016. Scaffolds from biomaterials: Advantages and limitations in bone and tissue engineering. Biologia 71(4): 353-366.

Amemiya, T., Nakaoka, K., Hamada, Y. \& Hayakawa, T. 2012. Effect of porosity of titanium web on cortical bone response. Journal of Hard Tissue Biology 21(2): 103-108.

Arifin, A., Sulong, A.B., Fun, L.C. \& Yani, I. 2017. Porous titanium alloy/hydroxyapatite composite using powder compaction route. Journal of Mechanical Engineering and Sciences 11(2): 2679-2692.

Asadi-Eydivand, M., Solati-Hashjin, M. \& Abu Osman, N.A. 2018. Mechanical behavior of calcium sulfate scaffold prototypes built by solid free-form fabrication. Rapid Prototyping Journal 24(8): 1392-1400.

Aslam, M., Ahmad, F., Yusoff, P.B., Muhamad, N., Raza, M.R. \& Shirazi, M.I. 2014. Effects of admixed titanium on densification of $316 \mathrm{~L}$ stainless steel powder during sintering. Volume 13. 4th International Conference on Production, Energy and Reliability, ICPER 2014 - Kuala Lumpur, Malaysia.

Barbas, A., Bonnet, A.S., Lipinski, P., Pesci, R. \& Dubois, G. 2012. Development and mechanical characterization of porous titanium bone substitutes. Journal of the Mechanical Behavior of Biomedical Materials 9: 34-44.

Chen, X.B., Li, Y.C., Hodgson, P.D. \& Wen, C. 2009. The importance of particle size in porous titanium and nonporous counterparts for surface energy and its impact on apatite formation. Acta Biomaterialia 5(6): 2290-2302.

Chocholata, P., Kulda, V. \& Babuska, V. 2019. Fabrication of scaffolds for bone-tissue regeneration. Materials 12(4): 568 .

Dabrowski, B., Swieszkowski, W., Godlinski, D. \& Kurzydlowski, K.J. 2010. Highly porous titanium scaffolds for orthopaedic applications. Journal of Biomedical Materials Research Part B: Applied Biomaterials 95(1): 53-61.

Fernando, S., McEnery, M. \& Guelcher, S. 2016. Polyurethanes for bone tissue engineering. Advances in Polyurethane Biomaterials 16: 481-501.

Fujibayashi, S., Neo, M., Kim, H.M., Kokubo, T. \& Nakamura, T. 2004. Osteoinduction of porous bioactive titanium metal. Biomaterials 25(3): 443-450.

Götz, H., Müller, M., Emmel, A., Holzwarth, U., Erben, R. \& Stangl, R. 2004. Effect of surface finish on the osseointegration of laser-treated titanium alloy implants. Biomaterials 25(18): 4057-4064.

Guyer, R.D., Abitbol, J.J., Ohnmeiss, D.D. \& Yao, C. 2016. Evaluating osseointegration into a deeply porous titanium scaffold: A biomechanical comparison with PEEK and allograft. Spine 41(19): 1146-1150.

Hayakawa, T., Takahashi, K., Okada, H., Yoshinari, M., Hara, H., Mochizuki, C., Yamamoto, H. \& Sato, M. 2008. Effect of thin carbonate-containing apatite (CA) coating of titanium fiber mesh on trabecular bone response. Journal of Materials Science: Materials in Medicine 19(5): 2087-2096. 
Hibi, H., Yamada, Y., Ueda, M. \& Endo, Y. 2006. Alveolar cleft osteoplasty using tissue-engineered osteogenic material. International Journal of Oral and Maxillofacial Surgery 35(6): 551-555.

Hoppe, A. \& Boccaccini, A. 2014. Bioactive glass foams for tissue engineering applications. Biomedical Foams for Tissue Engineering Applications 7: 191-212.

Jemat, A., Ghazali, M.J., Razali, M. \& Otsuka, Y. 2018. Microstructural, surface roughness and wettability of titanium alloy coated by YZP-30wt.\% tiO2 for dental application. Jurnal Teknologi 80(2): 45-50.

Karageorgiou, V. \& Kaplan, D. 2005. Porosity of 3D biomaterial scaffolds and osteogenesis. Biomaterials 26(27): 54745491 .

Kujala, S., Ryhänen, J., Danilov, A. \& Tuukkanen, J. 2003. Effect of porosity on the osteointegration and bone ingrowth of a weight-bearing nickel-titanium bone graft substitute. Biomaterials 24(25): 4691-4697.

Li, R.H. \& Wozney, J.M. 2001. Delivering on the promise of bone morphogenetic proteins. Trends in Biotechnology 19(7): 255-265.

Liu, L.S., Thompson, A.Y., Heidaran, M.A., Poser, J.W. \& Spiro, R.C. 1999. An osteoconductive collagen/hyaluronate matrix for bone regeneration. Biomaterials 20(12): $1097-$ 1108.

Loh, Q.L. \& Choong, C. 2013. Three-dimensional scaffolds for tissue engineering applications: Role of porosity and pore size. Tissue Engineering Part B: Reviews 19(6): 485-502.

Luthringer, B., Ali, F., Akaichi, H., Feyerabend, F., Ebel, T. \& Willumeit, R. 2013. Production, characterisation, and cytocompatibility of porous titanium-based particulate scaffolds. Journal of Materials Science: Materials in Medicine 24(10): 2337-2358.

Mediaswanti, K., Wen, C., Ivanova, E., Berndt, C., Malherbe, F., Pham, V. \& Wang, J. 2013. A review on bioactive porous metallic biomaterials. J. Biomim. Biomater. Tissue Eng. 18: 104. doi:10.4172/1662-100X.1000104.

Meng, W., Zhou, Y., Zhang, Y., Cai, Q., Yang, L. \& Wang, B. 2013. Effects of hierarchical micro/nano-textured titanium surface features on osteoblast-specific gene expression. Implant Dentistry 22(6): 656-661.

O’brien, F.J. 2011. Biomaterials \& scaffolds for tissue engineering. Materials Today 14(3): 88-95.

Otsuki, B., Takemoto, M., Fujibayashi, S., Neo, M., Kokubo, T. \& Nakamura, T. 2006. Pore throat size and connectivity determine bone and tissue ingrowth into porous implants: Three-dimensional micro-CT based structural analyses of porous bioactive titanium implants. Biomaterials 27(35): 5892-5900.

Pattanayak, D.K., Fukuda, A., Matsushita, T., Takemoto, M., Fujibayashi, S., Sasaki, K., Nishida, N., Nakamura, T. \& Kokubo, T. 2011. Bioactive Ti metal analogous to human cancellous bone: Fabrication by selective laser melting and chemical treatments. Acta Biomaterialia 7(3): 1398-1406.

Rakhmatia, Y.D., Ayukawa, Y., Furuhashi, A. \& Koyano, K. 2013. Current barrier membranes: Titanium mesh and other membranes for guided bone regeneration in dental applications. Journal of Prosthodontic Research 57(1): 3-14.

Raza, M.R., Sulong, A.B., Muhamad, N., Akhtar, M.N. \& Rajabi, J. 2015. Effects of binder system and processing parameters on formability of porous Ti/HA composite through powder injection molding. Materials \& Design 87: 386-392.
Simon, J.L., Roy, T.D., Parsons, J.R., Rekow, E.D., Thompson, V.P., Kemnitzer, J. \& Ricci, J.L. 2003. Engineered cellular response to scaffold architecture in a rabbit trephine defect. Journal of Biomedical Materials Research 66(2): 275-282.

Stangl, R., Rinne, B., Kastl, S. \& Hendrich, C. 2001. The influence of pore geometry in cp Ti-implants-A cell culture investigation. Eur. Cell Mater. 2(2): 1-9.

Sul, Y.T., Johansson, C.B., Petronis, S., Krozer, A., Jeong, Y., Wennerberg, A. \& Albrektsson, T. 2002. Characteristics of the surface oxides on turned and electrochemically oxidized pure titanium implants up to dielectric breakdown: The oxide thickness, micropore configurations, surface roughness, crystal structure and chemical composition. Biomaterials 23(2): 491-501.

Tamaddon, M., Samizadeh, S., Wang, L., Blunn, G. \& Liu, C. 2017. Intrinsic osteoinductivity of porous titanium scaffold for bone tissue engineering. International Journal of Biomaterials 2017: 5093063.

Thavornyutikarn, B., Chantarapanich, N., Sitthiseripratip, K., Thouas, G.A. \& Chen, Q. 2014. Bone tissue engineering scaffolding: Computer-aided scaffolding techniques. Progress in Biomaterials 3(2-4): 61-102.

Torres-Sanchez, C., Al Mushref, F., Norrito, M., Yendall, K., Liu, Y. \& Conway, P.P. 2017. The effect of pore size and porosity on mechanical properties and biological response of porous titanium scaffolds. Materials Science and Engineering: C 77: 219-228.

Van Bael, S., Chai, Y.C., Truscello, S., Moesen, M., Kerckhofs, G., Van Oosterwyck, H., Kruth, J.P. \& Schrooten, J. 2012. The effect of pore geometry on the in vitro biological behavior of human periosteum-derived cells seeded on selective laser-melted Ti6Al4V bone scaffolds. Acta biomaterialia 8(7): 2824-2834.

van den Dolder, J. \& Jansen, J.A. 2007. Titanium fiber mesh: A nondegradable scaffold material. Engineering of Functional Skeletal Tissues 3: 69-80.

Van der Stok, J., Van der Jagt, O.P., Amin Yavari, S., De Haas, M.F., Waarsing, J.H., Jahr, H., Van Lieshout, E.M., Patka, P., Verhaar, J.A. \& Zadpoor, A.A. 2013. Selective laser melting-produced porous titanium scaffolds regenerate bone in critical size cortical bone defects. Journal of Orthopaedic Research 31(5): 792-799.

Vehof, J.W., de Ruijter, A.E., Spauwen, P.H. \& Jansen, J.A. 2001. Influence of rhBMP-2 on rat bone marrow stromal cells cultured on titanium fiber mesh. Tissue Engineering 7(4): 373-383.

Wysocki, B., Idaszek, J., Szlązak, K., Strzelczyk, K., Brynk, T., Kurzydłowski, K.J. \& Święszkowski, W. 2016. Post processing and biological evaluation of the titanium scaffolds for bone tissue engineering. Materials 9(3): E197. doi: 10.3390/ma9030197.

Yazid, M.D., Zainal Ariffin, S.H., Senafi, S., Zainal Ariffin, Z. \& Megat Abdul Wahab, R. 2011. Stem cell heterogeneity of mononucleated cells from murine peripheral blood: Molecular analysis. The Scientific World Journal 11: 21502159 .

Rohaya Megat Abdul Wahab*, Manal Nabil Hagar, Nur Atmaliya Luchman \& Farinawati Yazid

Centre for Family Oral Health

Universiti Kebangsaan Malaysia

Jalan Raja Muda Aziz

50300 Kuala Lumpur, Federal Territory

Malaysia 
Shahrul Hisham Zainal Ariffin

Centre for Biotechnology and Functional Food

Faculty of Science and Technology

Universiti Kebangsaan Malaysia

43600 Bangi, Selangor Darul Ehsan

Malaysia

*Corresponding author; email: rohaya_megat@ukm.edu.my

Received: 8 February 2019

Accepted: 6 Disember 2019 